\title{
Investigation of High School Students' Peer Bullying Levels in Terms of Various Variables
}

\author{
Hilal Alkan ${ }^{1} \quad$ Nihan Arslan ${ }^{2}$
}

\begin{abstract}
In this study, it was aimed to examine the peer bullying levels of high school students in terms of various variables. The universe of the research consists of high school students in Istanbul. The research sample consists of 384 students. Descriptive analysis method was used in the research. In the study 'Information Form' and 'Peer Bullying Scale' were used as data collection tools. In the analysis of the data, Independent Groups t-Test, One Way Analysis of Variance were used. Within the scope of the research findings, It was determined that peer bullying differs significantly according to gender. It has been determined that male participants exhibit more bullying behaviors than female participants. When peer bullying scores were examined according to school type, it was determined that there was no significant difference. The research findings are discussed in the context of the literature.
\end{abstract}

Keywords: Peer bullying, high school, scale, students.

\section{Introduction}

There are different situations and environments where individuals interact with each other. Although one of the main goals of schools is to improve students' communication and problem solving abilities, the relationships students have with their friends may not be as expected in all situations (Karagöz, 2016; Kaya, 2020). One of the most important problems with students in the education process is bullying. Bullying, a concept that can be defined as a strong student behaving in a repetitive way to disturb the weaker student. A large number of individuals who are currently adults have probably been in many situations related to bullying / victimization during their school years or had an experience related to bullying by witnessing these situations (Ayas \& Pişkin, 2001). Bullying has been defined as a repetitive subset of aggression based on the imbalance of power between the bully and the victim. Bullying behaviors include direct physical aggression, direct verbal aggression, and indirect aggression. Bullying is a type of co-victimization that enhances the traits of the harm and imbalance of power. Bullying is often defined as repetitive, aggressive and deliberate behavior that is used (physical, psychological or emotional) to cause harm or distress. The behavior must include an imbalance of power. Perceived (or real) power imbalance often arises with physical dimension or power, popularity, intelligence, or a form of incompetence. Also, the behavior must occur over and over again. Repetition of the behavior can create a greater inequality in the relationship between the victim and the bully, and make it more difficult for the victim to avoid feeling uncomfortable (Craig et al., 2007; O'Connell et al., 1999). Being exposed to bullying behaviors can be considered a serious trauma for every student, the effects of this situation are not limited to the school period but continue throughout the life of the individual and from the perspective of society, it also affects the mental health of individuals

\footnotetext{
1 alknhilal@hotmail.com, orcid.org/0000-0002-1813-1004

2 Necmettin Erbakan University, nihan.arslan@erbakan.edu.tr, ORCID: 0000-0002-2451-0852
} 
negatively. When bullying behavior becomes repetitive and continuous and the difference in the balance of power is permanent, this situation harms the physical and mental development context of children who are exposed to bullying. In children who are exposed to peer bullying, internal problems such as psychosomatic symptoms and depression increase. Many studies reveal that students who are exposed to bullying face various psychological problems (Üneri, 2011).

Violence tendency and bullying are two concepts that are based on the concept of aggression and share a common denominator with each other. Considering the behaviors that are within the scope of bullying, the individual demonstrates these behaviors with the aim of harming the other person, continuously doing harm but not for the purpose of self-protection (Kaya, 2020). Bullying which can be defined as a form of violence is simply that students as group exercise force against other students and behave in a way that could harm them (Ural \& Öztek, 2010). Schools are among the places where peer bullying is seen most frequently. Bullying within the school can also be seen in the relationships between teacher and student (Karagöz \& Rüzgar, 2020). However, although these behaviors push the teacher or the student into the category of bully, it may not be qualified as a bully in this context. In other words, an individual's behavior that can be considered in the category of bullying behavior may not make that individual a bully (Arslan \& Yeşilyurt, 2019). Some bullying behaviors can also occur in relationship conflicts. Therefore, it is important and necessary to distinguish between bullying and relationship conflicts. In this study, it was aimed to examine the peer bullying levels of high school students in terms of various variables.

\section{Method}

Descriptive analysis method was used in the research. The universe of the research consists of high school students studying in Istanbul. The sample group of the study consists of a total of 384 high school students, including 145 anatolian high schools, 117 science high schools and 122 vocational high schools. The rate of female participants is $57.6 \%$ with 221 people and male participants is $42.4 \%$ with 163 people.

\section{Data Collection Tools}

The 'Information Form ' was used to obtain information about the demographic characteristics of the participants in the study and the 'Peer Bullying Scale (PBS)' to collect data on peer bullying levels. The 'Information Form' developed by the researcher was used to gather information about the grade level, gender, and school type of the individuals in the sample group.

\section{Peer Bullying Scale}

Peer Bullying Scale is a measurement tool developed by Shaw et al. (2013) to determine cyberbullying behaviors. The scale consists of a total of 10 items in 5-point Likert type and a single subdimension. The items in the scale are answered in the range of 1 to 5 for (1) I did not, (2) I did it once or twice, (3) I did it once a month, (4) I did it once a week, and (5) I did it several times a week. The adaptation study of the scale into Turkish was conducted by Arslan (2017). As a result of the reliability analysis, the Cronbach's Alpha internal consistency reliability coefficient of the scale was calculated as .86 . The validity of the scale was evaluated with the construct validity and the Bartlett test $\chi^{2}$ coefficient was calculated as 192.22. As a result of the factor analysis calculated; $x^{2}=198.22$, DF $=33, p=$ 
0.00, $\mathrm{RMSEA}=.11, \mathrm{NFI}=.94, \mathrm{NNFI}=.93, \mathrm{CFI}=.95, \mathrm{IFI}=.95, \mathrm{IFI}=.95, \mathrm{SRMR}=.61$. Cronbach's Alpha internal consistency reliability value of the scale was calculated as .76 for this study.

\section{Findings}

Minimum-maximum values, skewness-kurtosis values and standard errors, mean and standard deviation values for Peer Bullying Scale scores are given in Table 1.

\section{Table 1}

Descriptive Statistics

\begin{tabular}{lllllllll}
\hline Scales & Min & Max & Skewness & SE & Kurtosis & SE & $x^{-}$ & SD \\
\hline Peer Bullying Scale (PBS) & 10 & 38 & 1.243 & .125 & 1.458 & .248 & 16,27 & 5.47 \\
\hline
\end{tabular}

The range was calculated for the Peer Bullying Scale, as 10-38, skewness $=1.243$ and standard error $=$ 125 , kurtosis $=1.458$ and standard error $=, 248$ mean $=16.27$ and standard deviation $=5.47$.

Table 2

T-Test Results on the Peer Bullying Scale by Gender Variable

\begin{tabular}{|c|c|c|c|c|c|c|c|}
\hline Scale & Variable & $\mathrm{N}$ & $x^{-}$ & SD & $t$ & $\mathrm{DF}$ & $p$ \\
\hline \multirow{3}{*}{ Peer Bullying Scale } & Woman & 221 & 15,22 & 4.72 & \multirow{3}{*}{-4.300} & \multirow{3}{*}{295.212} & \multirow{3}{*}{$.000^{* *}$} \\
\hline & & & & & & & \\
\hline & Male & 163 & 17.68 & 6.08 & & & \\
\hline
\end{tabular}

${ }^{*} p<0.05 ;{ }^{* *} p<0.01$

Based on the Table 2, there is a statistically significant difference between the Peer Bullying Scale scores of female and male participants $\left(t_{(295,212)}=-4.300 ; p<0.01\right)$. It was determined that male participants' Peer Bullying Scale mean scores were higher than female participants.

Table 3

ANOVA Results on the Comparison of Peer Bullying Scale Scores According to the School Type Variable

\begin{tabular}{|c|c|c|c|c|c|c|c|}
\hline Scale & Variable & $\mathrm{N}$ & $x^{-}$ & SD & $F$ & $\mathrm{DF}$ & $p$ \\
\hline \multirow{4}{*}{ Peer Bullying Scale } & Anatolian High School & 145 & 16.65 & 5.34 & \multirow{4}{*}{2.323} & \multirow{4}{*}{$\begin{array}{l}2 \\
381\end{array}$} & \multirow{4}{*}{.099} \\
\hline & & & & & & & \\
\hline & Science High School & 117 & 15.36 & 5.15 & & & \\
\hline & Vocational High School & 122 & 16.68 & 5.86 & & & \\
\hline
\end{tabular}

Based on the Table 3, it was determined that the Peer Bullying Scale total score did not differ significantly according to the school type variable $(p>0.05)$. 
Table 4

ANOVA Results on the Comparison of Peer Bullying Scale Scores by Class Level Variable

\begin{tabular}{llllllll}
\hline Scale & Variable & $\mathrm{N}$ & $x^{-}$ & SD & $F$ & DF & $p$ \\
\hline & 9th grade & 78 & 16.44 & 4.73 & & & \\
& Grade 10 & 104 & 16.56 & 6,07 & & 3 & \\
Peer Bullying Scale & 11th grade & 91 & 15.53 & 4.84 & & 208.135 & $.470^{\text {a }}$ \\
& Class 12 & 111 & 16.48 & 5.87 & & & \\
& & & & & & & \\
\hline
\end{tabular}

${ }^{*} p<0.05 ;{ }^{* *} p<0.01 ;$ Welch Statistics ${ }^{\mathrm{a}}$

Based on the Table 4, it was determined that Peer Bullying Scale scores did not differ significantly according to the class level variable $(p>0.05)$.

\section{Discussion}

In the light of the findings obtained from the research results, it was determined that peer bullying differs significantly according to gender. Male participants display bullying behaviors more than female participants. When the studies in the literature were examined, it was seen that there were many studies supporting the findings of this study. Similar findings obtained in studies on peer bullying and gender (Kapıkıran \& Fiyakal1, 2003; Arslan \& Yeşilyurt, 2019). When the peer bullying scores of the participants were examined according to the type of school, the peer bullying scores did not differ significantly according to the school type variable. When the studies in the literature are examined, it is determined that there are studies that reveal many different findings. Ayas and Pişkin (2011) examined the bullying levels of the students according to the type of school in the sample of high school students and determined that the physical and verbal bullying scores of the participants who were educated in private high schools were higher than those of the anatolian high school students When the peer bullying scores of the participants were examined according to the type of school, it was determined that the peer bullying scores did not differ significantly according to the class variable. When the studies in the literature were examined, Atik et al. (2012) found that students' bullying behaviors did not differ in terms of school type. Totan and Kabakçı (2010) reported that as class level increases, bullying decreases. In the light of the findings of this research, some suggestions are listed. Many students in the sample group of the study have problems in their social relations and exhibit behaviors that can be considered bullying. During the education process, these students can be determined by using the measurement tools used in this research or similar and necessary interventions can be made. Peer mediation training should be done starting from primary school, especially at secondary and high school levels. Conducting experimental and longitudinal studies by researchers is very important for future research. 


\section{References}

Arslan, N. (2017). Peer bullying among high school students: Turkish version of bullying scale. Turkish Online Journal of Educational Technology-TOJET. 853-857.

Arslan, S., \& Yeşilyurt, F. (2019). Ergenlerin sanal zorbalık düzeylerinin bazı değişkenler açısından incelenmesi. OPUS- Uluslararası Toplum Araştırmaları Dergisi, 11(18), 27-42. DOI: 10.26466/opus.515067.

Atik, G., Özmen, O., \& Kemer, G. (2012). Bullying and submissive behavior. Ĕ̆gitim Bilimleri Fakultesi Dergisi, 45(1), 191.

Ayas, T., \& Pişkin, M. (2011). Investigation of bullying among high school students with regard to sex, grade level and school type. Elementary Education Online, 10(2), 550-568.

Craig, W. M., Pepler, D. J., \& Blais, J. (2007). Responding to bullying: What works? International Journal of School Psychology, 28, 15-24.

Kapıkıran Acun, N., \& Fiyakalı, C. (2003). Lise öğrencilerinde akran baskısı ve problem çözme. Pamukkale Üniversitesi Ĕ̆itim Fakültesi Dergisi, 18(18), 11-17.

Karagöz, S., \& Rüzgar, M. (2020). The observations of student teachers in regard to professional qualifications of advisor teachers during teaching practicum. International Journal of Educational Research Review, 5(2), 141-150. DOI: 10.24331/ijere.691323.

Karagöz, S. (2016). Opinions and suggestions regarding various subjects on the educational guidance in the second constitutional era. Journal of Family, Counseling, and Education, 1(1), 1-9.

Kaya, İ. (2020). Investigation of the relationship of physical and relational aggression of preschool children with temperament characteristics. Journal of the Human and Social Sciences Researches, 9(5), 3361-3378.

Kaya, İ. (2020). The investigation of children's persistent and reactive behavior with respect to parenting attitudes. International Journal of Progressive Education, 16(6), 273-282.

O'Connell, P., Pepler, D., \& Craig, W. (1999). Peer involvement in bullying: Insights and challenges for intervention. Journal of Adolescence, 22, 437-452.

Shaw, T., Dooley, J. J., Cross, D., Zubrick, S. R., \& Waters, S. (2013). The Forms of bullying scale (FBS): Validity and reliability estimates for a measure of bullying victimization and perpetration in adolescence. Psychological assessment, 25(4), 1045.

Totan, T., \& Kabakçı, Ö. F. (2010). İlköğretim ikinci kademe öğrencilerinde sosyal duygusal öğrenme becerilerinin zorbalı̆̆1 yordama gücü. Uludă̆ Üniversitesi Ĕ̆itim Fakültesi Dergisi, 23(2), 575-600.

Ural, B., \& Özteke, N. (2010). Okulda zorbalık. Ankara: Kök Yayıncllık.

Üneri, Ö. S. (2011). Çocuklarda akran zorbalığı. Düşünen Adam, 24(4), 352-353. 